\title{
Development and in vitro characterisation of novel bioresorbable and bioactive composite materials based on polylactide foams and Bioglasss for tissue engineering applications
}

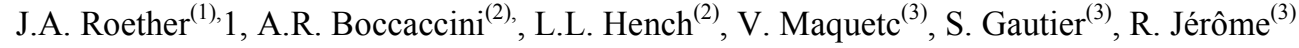 \\ (1) Centre for Composite Materials, Imperial College, London SW7 2BY, UK \\ (2) Department of Materials and Centre for Tissue Engineering, Imperial College, London SW7 2BP, UK \\ (3) Centre for Education and Research on Macromolecules (CERM), Interfacultary Centre for Biomaterials, \\ University of Liège, B-4000 Liège, Belgium
}

\begin{abstract}
Bioactive and bioresorbable composite materials were fabricated using macroporous poly(DL-lactide) (PDLLA) foams coated with and impregnated by bioactive glass (Bioglass $\left.{ }^{\circledR}\right)$ particles. Stable and homogeneous Bioglasss coatings on the surface of PDLLA foams as well as infiltration of Bioglass ${ }^{\circledR}$ particles throughout the porous network were achieved using a slurry-dipping technique in conjunction with pre-treatment of the foams in ethanol. The quality of the bioactive glass coatings was reproducible in terms of thickness and microstructure. Additionally, electrophoretic deposition was investigated as an alternative method for the fabrication of PDLLA foam/Bioglass ${ }^{\circledR}$ composite materials. In vitro studies in simulated body fluid (SBF) were performed to study the formation of hydroxyapatite (HA) on the surface of PDLLA/Bioglass ${ }^{\circledR}$ composites. SEM analysis showed that the HA layer thickness rapidly increased with increasing time in SBF. The high bioactivity of the PDLLA foam/Bioglasss composites indicates the potential of the materials for use as bioactive, resorbable scaffolds in bone tissue engineering.
\end{abstract}

Keywords: Bioresorbable composites; Bioactivity; Polylactide foams; Bioglass ${ }^{\circledR}$; Tissue engineering

\section{Introduction}

Tissue engineering presents an alternative approach to the repair of a damaged tissue, avoiding the need for a permanent implant made of an engineered material. The underlying principle involved is the regeneration of living tissue, where a loss or damage has occurred as a result of injury or disease [1]. A suitable temporary scaffold material exhibiting adequate mechanical and biological properties is required to enable tissue regeneration by exploiting the body's inherent repair mechanisms, i.e. a regenerative allograft [2].

Numerous bioresorbable materials have been investigated as scaffolds for tissue engineering and tissue repair, including naturally occurring $[3,4]$ and synthetic polymers [5-8]. Many practical advantages arise when using synthetic scaffolds because precise engineering of material composition and micro- and macrostructure is possible. This allows adequate control of scaffold properties, thus creating optimal conditions for cell survival, proliferation, and subsequent tissue formation [6].

Synthetic bioresorbable polymers have attracted increasing attention for their use as tissue engineering scaffolds in the last 10 years, in particular polylactic acid (PLA), polyglycolic acid (PGA) and their copolymers [6-8]. These materials have already demonstrated promising results in clinical use, for example as resorbable surgical sutures and meshes or in drug delivery systems [6]. However, a number of problems have been encountered regarding the use of these polymers in tissue engineering applications due to the release of acidic degradation products leading to inflammatory responses [5-8]. Another limitation of biodegradable polymers is that they lack a bioactive function, i.e., in particular for bone tissue applications, they do not allow for bone apposition or bonding on the polymer surface [9].

Certain ceramic materials, such as hydroxyapatite (HA), tricalcium phosphate (TCP) and selected compositions of silicate and phosphate glasses and glass-ceramics, for example the commercially available Bioglass ${ }^{\circledR}$, react with physiological fluids and form tenacious bonds to hard and soft tissues through cellular activity. These materials are therefore known as "bioactive" [10].

If biodegradability and bioactivity are to be combined in an optimised tissue engineering scaffold, then the design of composite materials offers an exceptional opportunity: composites allow for the creation of bioresorbable and bioactive scaffolds with tailored physical and mechanical properties [11]. Moreover, composite materials can be engineered in such a way that their resorption rate in the body matches the formation rate of new tissue.

Various approaches to the development of bioresorbable and bioactive composites for tissue engineering applications are being investigated worldwide, including combinations of polylactide (PLA), polyglycolide 
(PGA) and other resorbable polymers with HA, TCP or bioactive glasses and glass-ceramics in different scaffold architectures [11-18]. In the most usual approach, HA, TCP and bioactive glass particles or fibres are combined with bulk or porous polymeric biodegradable substrates either as fillers or in the form of coatings, as reviewed elsewhere [19].

In the present work novel bioactive and bioresorbable composite materials were fabricated using macroporous poly (DL-lactide) (PDLLA) foams coated with and impregnated by bioactive glass (Bioglass $\left.{ }^{\circledR}\right)$ particles. The in vitro response of the composites in contact with simulated body fluid (SBF) was assessed. The materials are intended as scaffolds for bone tissue engineering applications. This study extends related recent research on composite materials based on bioresorbable Bio-glasss-coated surgical sutures [20,21] and meshes [22].

\section{Experimental}

\subsection{Materials}

PDLLA foams were fabricated following a thermally induced phase separation process, also termed freezedrying and described in detail elsewhere [7a,b]. Briefly, 2g of PDLLA (Purasorbs; Purac biochem, Holland), with inherent viscosity $=1.52 \mathrm{dl} / \mathrm{g}$, was dissolved in $40 \mathrm{ml}$ of dimethylcarbonate $(99 \%$, Acros) under magnetic stirring overnight. The solution was transferred into a $150 \mathrm{ml}$ lyophilisation flask and frozen for $2 \mathrm{~h}$ by quenching into liquid nitrogen. The flask was then connected to a vacuum pump ( $\left.10^{-2} \mathrm{Torr}\right)$ and the solvent was sublimated at $-10^{\circ} \mathrm{C}$ for the first $48 \mathrm{~h}$, and then at $0^{\circ} \mathrm{C}$ for additional $48 \mathrm{~h}$. The residual solvent was then removed at room temperature until the foam reached a constant weight. Table 1 summarises some key properties of the foam material prepared in this work. A detailed characterisation of the foams' porous structure in relation to the processing and formulation parameters has been carried out in previous works using image analysis and impedance spectroscopy [23,24]. Moreover, the suitability of the foams in tissue engineering applications has been explored, in particular for repairing nerve sections, both in the peripheral and central nervous systems $[25,26]$.

The bioactive material used was a melt-derived bioactive glass powder (Bioglass ${ }^{\circledR}$ grade 45S5, US Biomaterials Co., Alachua, FL, USA). The powder had a mean particle size $<5 \mathrm{~mm}$. The composition of the bioactive glass used was (in weight percentage): $45 \% \mathrm{SiO}_{2}, 24.5 \% \mathrm{Na}_{2} \mathrm{O}, 24.5 \% \mathrm{CaO}$ and $6 \% \mathrm{P}_{2} \mathrm{O}_{5}$, which is the original composition of the first bioactive glass developed by Hench and co-workers in 1971 [27].

Table 1 Properties of the PDLLA foams prepared by freeze-drying a $5 \mathrm{wt}: \mathrm{v} \%$ solution in DMC

\begin{tabular}{ll} 
Density & $0.102 \pm 0.00 \mathrm{Sg} \mathrm{cm}^{-3}$ \\
Pore volume & $9.5 \pm 0.8 \mathrm{~cm}^{3} \mathrm{~g}^{-1}$ \\
Glass transition temperature $\left(T_{g}\right)$ & $51^{\circ} \mathrm{C}$ \\
Crystallinity & $0 \%$ \\
\hline
\end{tabular}

\subsection{Methods}

The composite materials were made using a slurry-dipping technique, similar to that proposed by Boccac-cini et al., to coat surgical sutures and polymeric meshes with Bioglass ${ }^{\circledR}$ particles $[21,22]$. The technique involved the preparation of a stable slurry with $42 \mathrm{wt} \%$ of Bioglass ${ }^{\circledR}$ particles in distilled and deionised water. The composition and concentration of the slurry were determined by an optimisation process based on a trial-anderror approach to achieve satisfactory results in terms of thickness, uniformity and stability of the Bioglass $\left({ }^{\circledR}<\right.$ coating as well as adequate infiltration of the glass particles into the pores of the foam. After magnetic stirring the slurry for $30 \mathrm{~min}$, the PDLLA samples were lowered into the slurry using tweezers and left in immersion for $5 \mathrm{~min}$. Following immersion, the samples were carefully withdrawn to avoid damage at a withdrawal velocity of $\sim 5 \mathrm{~cm} \mathrm{~s}^{-1}$. The samples were dried on glass plates at room temperature in humid atmosphere.

In a processing optimisation, pre-treatment of the PDLLA foams with ethanol was carried out at room temperature for various time durations, ranging from $30 \mathrm{~min}$ to $12 \mathrm{~h}$, following a procedure originally described by Mikos et al. [28]. It was anticipated that better results in terms of degree of infiltration and coating homogeneity would be achieved by the ethanol pre-treatment procedure because the high hydrophobi-city of the PDLLA foam would be decreased. After immersion in ethanol, the foams were dipped in the aqueous slurry, as described above, to complete the coating procedure. Immersion time in the slurry was 5 min. Drying was conducted at ambient temperature in a humid atmosphere as above.

An alternative method to infiltrate the porous foams was attempted using electrophoretic deposition (EPD). This technique, which relies on the presence of charged ceramic particles in a suspension, has been used extensively for coating and infiltration of ceramic particles onto different conducting and non-conducting porous and fibrous substrates, as reviewed elsewhere [29]. 
For the experiments carried out as part of this study, a slurry was made with $42 \mathrm{wt} \%$ of Bioglass ${ }^{\circledR}$ in distilled and deionised water. The EPD cell used is shown schematically in Fig. 1. The electrodes, made of stainless steel, were placed in the slurry with the foam situated in-between. The foam was placed such that the tubular (larger) pores were oriented horizontally, i.e. perpendicularly to the larger dimension of the electrodes. For these experiments, the foams were pretreated in ethanol, as described above. Different voltages were applied and several coating times were tried in order to determine the optimal processing conditions. It was found that best results were yielded with a voltage of $3 \mathrm{~V}$ and deposition time of $30 \mathrm{~s}$. Once the EPD process was complete, the foam samples were carefully retrieved from the EPD cell using tweezers and dried in a normal atmosphere at ambient temperature.

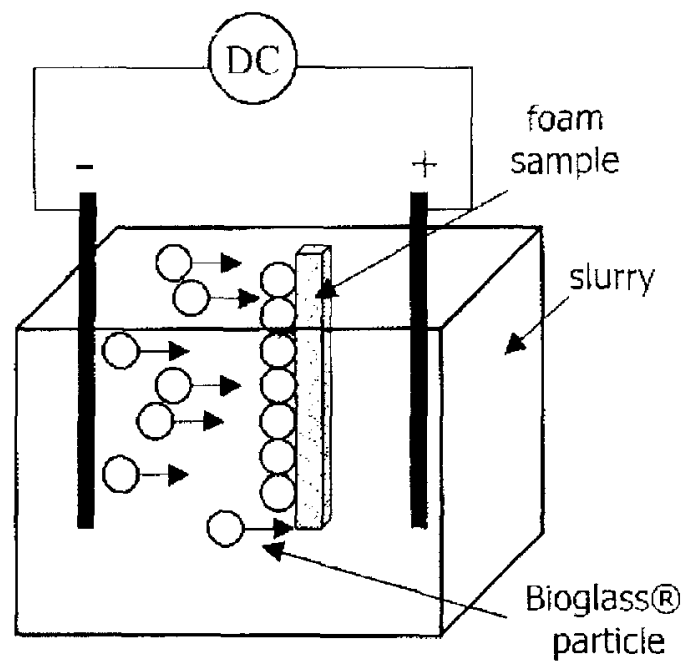

Fig. 1. EPD cell used for the fabrication of PDLLA foam/Bioglass ${ }^{\circledR}$ composites.

\subsection{Characterisation and in vivo studies}

Freeze-dried PDLLA foams and PDLLA/Bioglass ${ }^{\circledR}$ composite samples were characterised by using scanning electron microscopy (SEM), in order to assess the quality of the Bioglass ${ }^{\circledR}$ coating and degree of infiltration. Samples were gold-coated and observed at an accelerating voltage of 20-25 kV.

In vitro studies in SBF were carried out using the SBF composition and following standard procedures described by researchers at the University of Kyoto (Japan) [30]. Dry composite and uncoated PDLLA foams were immersed in $75 \mathrm{ml}$ of SBF in clean conical flasks, which had previously been washed using hydrochloric acid and deionised water. The conical flasks containing the foams were placed inside an orbital shaker (New Brunswick Scientific, C24 Incubator Shaker), which rotated at $175 \mathrm{rpm}$ at a controlled temperature of $37^{\circ} \mathrm{C}$. The PDLLA foam/Bioglass ${ }^{\circledR}$ composites and uncoated foams were left in immersion in SBF for varying time periods of 7, 14, 21 and 28 days. The SBF was changed every 7 days as cation concentration decreased during the course of in vitro studies, as a result of the changes in the chemistry of the samples, as discussed below. After immersion in SBF the samples were characterised using SEM. X-ray diffraction (XRD) analysis was used to verify whether or not HA had been formed on the surfaces of samples treated in SBF.

\section{Results}

\subsection{Materials characterisation}

The SEM morphology of a PDLLA foam prepared by freeze-drying is shown in Fig. 2. The foam possesses two distinct pores sizes, macropores of $\geq 100 \mathrm{~mm}$ average diameter and micropores with an average diameter of 20-30 $\mu \mathrm{m}$, which form an interconnected network. The tubular macropores were highly oriented as a result of the unidirectional cooling process. This kind of morphology is typically formed after freeze-drying of poly $(\alpha-$ hydroxyacid) [7a,b], including polylactide and copolymers of $\varepsilon$-caprolactone with lactide or glycolide in solvents such as dioxane and dimethylcarbonate.

PDLLA foam/Bioglass ${ }^{\circledR}$ composites were fabricated using both slurry-dipping and EPD techniques. Pretreatment of PDLLA foams with ethanol was required in order to decrease the hydrophobicity of the material, thus enabling easier handling of foams for further processing and enhanced Bioglass $\AA$ particle penetration into the porous network. It was observed that ethanol pre-treatment resulted in both a more stable polymer/Bioglass ${ }^{\circledR}$ interface and greater adherence between Bioglass ${ }^{\circledR}$ particles and PDLLA foam (assessed qualitatively). Samples were slowly dried at ambient temperature to reduce the occurrence of microcracks. 


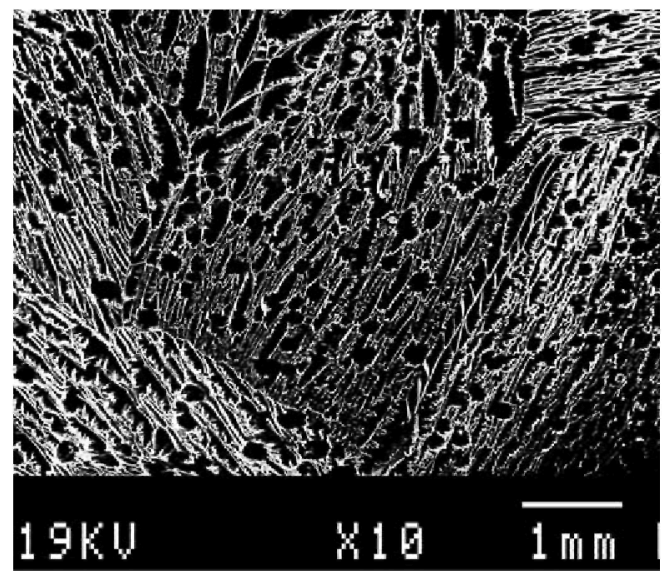

(a)

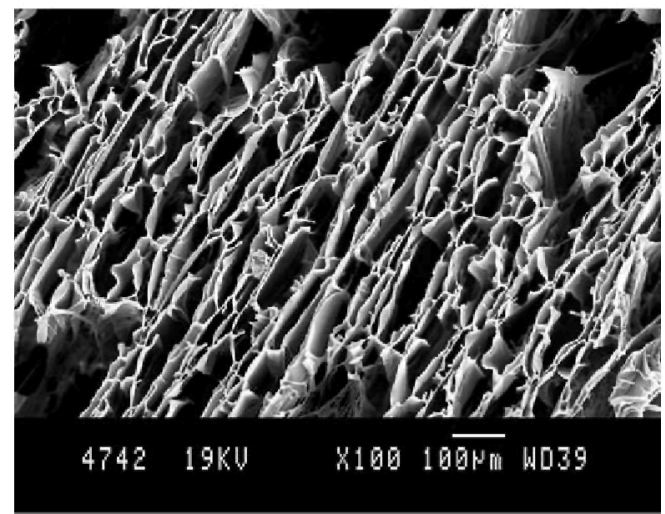

(b)

Fig. 2. SEM micrograph showing a typical cross-section of the PDLLA freeze-dried foams at low (a) and high (b) magnification.

Figs. 3 and 4 show SEM micrographs of PDLLA foam/Bioglass ${ }^{\circledR}$ composite samples produced by slurrydipping at different magnifications. Neither peeling-off of Bioglass ${ }^{\circledR}$ particles nor macro-delamination of the Bioglass ${ }^{\circledR}$ coating was observed. It can be observed that the material exhibits a thin, even film of Bioglass ${ }^{\circledR}$ that covers the surface of the foam. Using an immersion time of $5 \mathrm{~min}$, the Bioglass ${ }^{\circledR}$ particles have also deeply infiltrated the pores of the material and glass particles are deposited evenly along the internal surfaces of the porous structure. It should also be highlighted that coatings fabricated by the optimised slurry-dipping technique were homogeneous not only inside the pores but also on the outer surfaces of the foam. Moreover, the microstructure of the Bioglass ${ }^{\circledR}$ coating was highly reproducible and its typical feature, e.g. porosity, was the result of the narrow size distribution of the Bioglass ${ }^{\circledR}$ particles used.

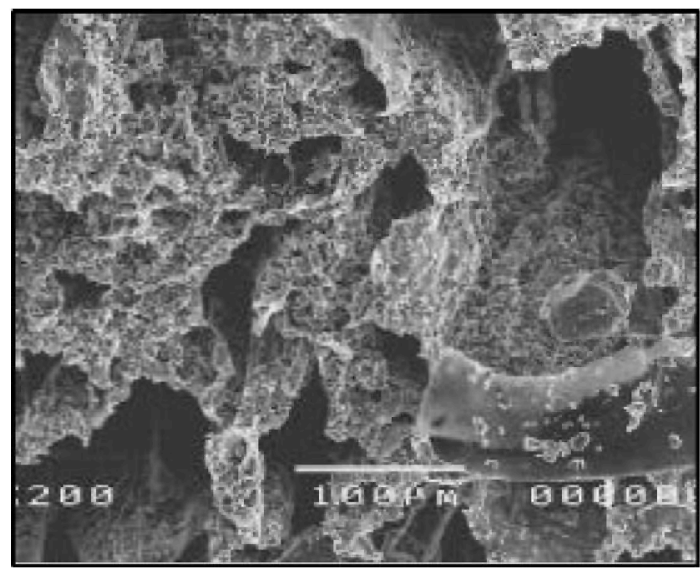

Fig. 3. SEM micrograph showing the microstructure of a PDLLA foam/Bioglass ${ }^{\circledR}$ composite sample produced 
by slurry dipping. The efficient infiltration of Bioglasss particles into the pores can be observed.

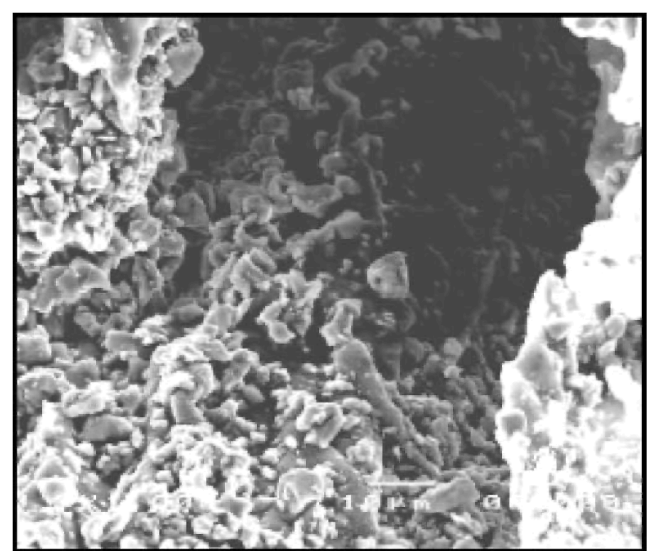

Fig. 4. SEM image of Bioglasss particle infiltration into the porous network of PDLLA foam at high magnification, showing homogeneous coating microstructure.

The EPD technique with a relatively small deposition voltage of $3 \mathrm{~V}$ and a short coating time of $30 \mathrm{~s}$ deposited a thick layer of Bioglass ${ }^{\circledR}$ particles on the outer surface of the foams and it efficiently filled the pores. Fig. 5 illustrates a Bioglass $® / P D L L A$ foam composite which was fabricated by the EPD route. SEM observation demonstrated that EPD could be used to fill completely the micropores of the foam with Bioglass ${ }^{\circledR}$ particles. The same effect was observed for the tubular macro-pores.

Comparing the results for slurry-dipping and EPD, it can be concluded that for the purpose of infiltrating the present PDLLA foams with Bioglass ${ }^{\circledR}$ particles, slurry-dipping offers better control of the coating thickness and a more uniform coating microstructure through the foam cross section. Since the thickness and microstructure of the Bioglass ${ }^{\circledR}$ coating will influence the degradation behaviour of the composite material, an even, uniform and reproducible coating along the walls of pores is required. Moreover, for cell proliferation, tissue engineering scaffolds are required to possess sufficient pore volume, as well as pores of a given, controlled size [31]. In the interior of the composite foams fabricated by EPD, however, the original interconnected porous structure of the foam became "sealed" by the Bioglass ${ }^{\circledR}$ particles, and therefore, this technique was found to be inadequate for the purpose of fabricating porous composite scaffolds, at least for the conditions investigated here. However, this technique could be relevant for fabricating bioresorbable fracture fixation devices, in which mechanical properties and structural integrity are more important issues than porosity [32].

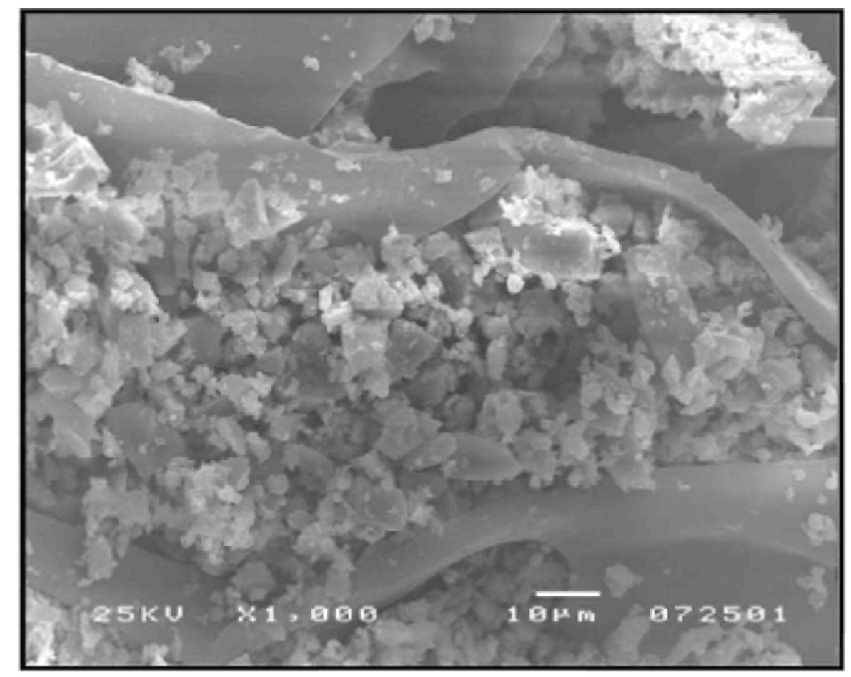

Fig. 5. SEM micrograph showing the microstructure of PDLLA foam/bioglass ${ }^{\circledR}$ composite produced by EPD. Interconnected pores became "sealed" with bioglass ${ }^{\circledR}$ particles.

\subsection{In vitro studies in $S B F$}

The response of PDLLA foams and PDLLA foam/ bioglass ${ }^{\circledR}$ composites in contact with SBF was analysed qualitatively using SEM and XRD. Figs. 6(a)-(d) show the gradual development of a HA layer, as confirmed by 
XRD analyses (see below), on the surface of the coated composite samples as a result of increasing days of immersion in SBF, i.e. after 7, 14, 21 and 28 days.

The results were compared to those of uncoated PDLLA foam samples, which were also immersed in SBF for varying times. Fig. 7 shows a SEM micrograph of an uncoated PDLLA sample after 28 days of immersion in SBF. It is apparent that no HA crystals are formed as a result of contact of this uncoated material with SBF. However changes in the pore morphology of the PDLLA foam as a result of progressive polymer degradation was observed with increasing number of days in SBF. These morphological changes became visually obvious after 28 days in SBF, as Fig. 7 shows.

For the composite samples, the crystallinity of the structure formed on the surface of the foams was investigated using XRD, as shown in Fig. 8. XRD confirmed that HA formation took place on the composites surface after immersion in SBF. Since the analysed samples varied in size and morphology, a quantitative analysis revealing the amount of HA formed in dependence of immersion time in SBF could not be carried out.

Nevertheless, the in vitro studies were successful in confirming the high ability for HA formation on the composite surfaces, which is a measure of the considerable bioactivity of the material [10]. It was confirmed that an HA layer formed within few days of immersion in SBF. As Figs. 6(a)-(d) show, the structure and morphology of the HA layer changed during immersion in SBF. Small HA crystals deposited after the first week of immersion, which developed into a continuous HA layer formed by coalescence of large crystals after the third week of immersion in SBF.

The HA layer formed on the composite surfaces was relatively thick, compared to other studies reported in the literature, where HA was used as the bioactive component in bioresorbable composites. For example, Ma et al. [18] reported that the thickness of the surface HA layer on their HA-containing composites was only $1 \mu \mathrm{m}$ after 21 days of in vitro degradation in SBF.

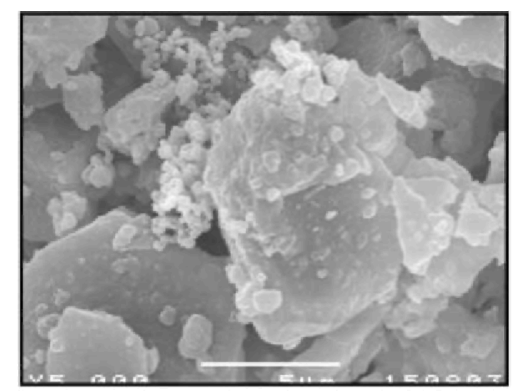

(a)

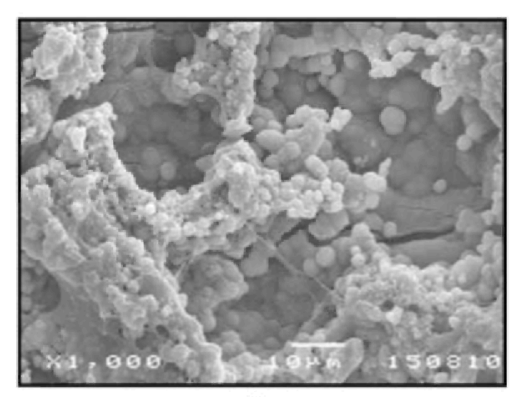

(c)

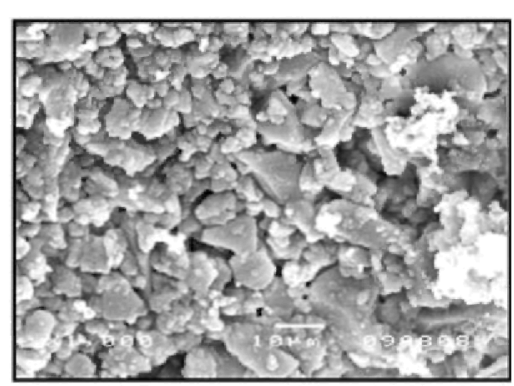

(b)

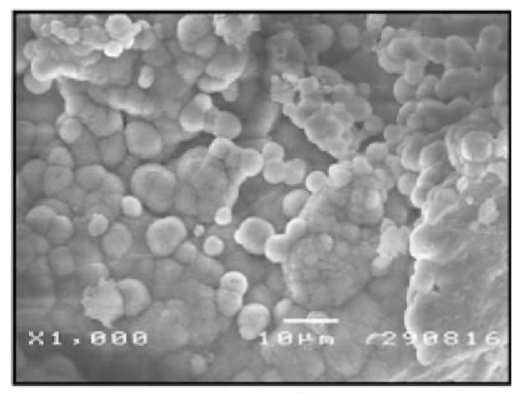

(d)

Fig. 6. SEM micrographs showing surfaces of PDLLA/bioglass ${ }^{\circledR}$ composite samples after degradation in contact with SBF for: (a) 7 days, (b) 14 days, (c) 21 days and (d) 28 days. The micrographs reveal progressive formation of HA crystals and development of a surface HA layer. 


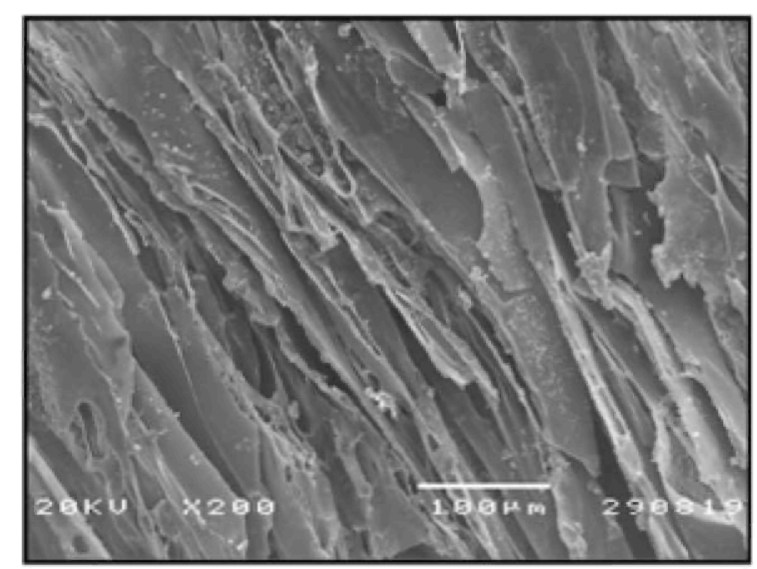

(a)

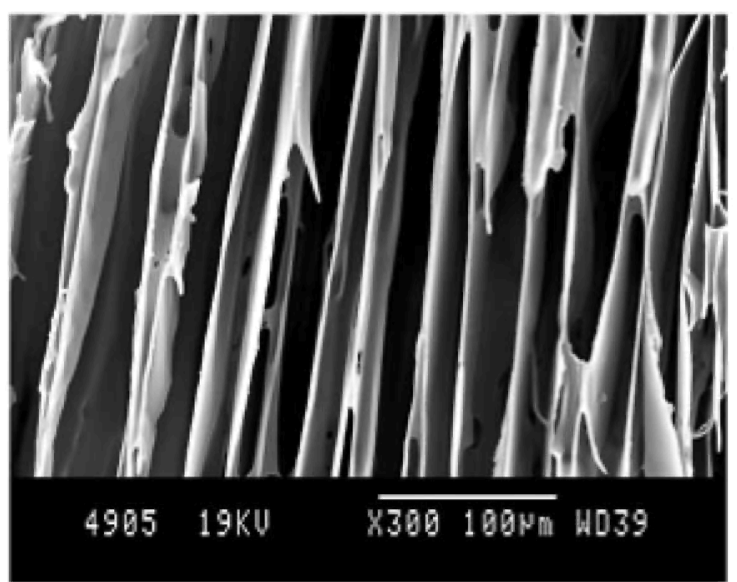

(b)

Fig. 7. (a) SEM micrograph of an uncoated PDLLA foam after 28 days immersion in SBF showing partial degradation of the polymer but no HA formation. For comparison, a similar magnification SEM micrograph of an as-fabricated foam is shown (b).

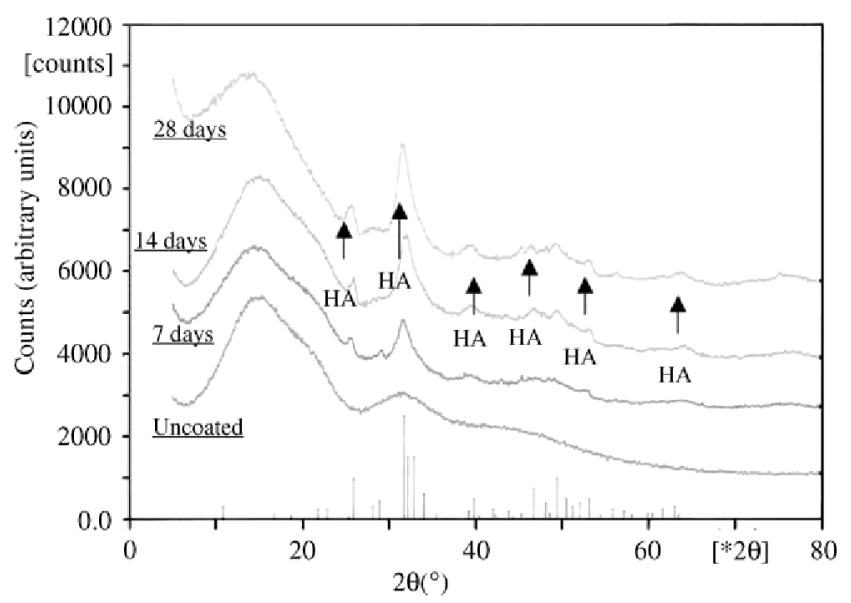

Fig. 8. XRD pattern of PDLLA foam/bioglass ${ }^{\circledR}$ composites after in vitro studies in SBF for 7, 14 and 28 days, showing development of HA. The pattern of an uncoated PDLLA foam is also shown. Note that the intensity is given in arbitrary units, i.e. the relative height of the peaks does not correlate with the relative amount of HA present in the different samples.

In our investigation, the thickness of the HA layer formed on bioglass ${ }^{\circledR}$-coated surfaces was increased manifold, an indication of the enhanced bioactivity of the materials. After 21 days in SBF, for example, the HA layer had a thickness of $\sim 10 \mu \mathrm{m}$, as determined by SEM examination of sample cross-sections. It is well known that bioglass ${ }^{\circledR}$ has a higher index of bioactivity than HA, which makes it a more suitable material for applications in bone reconstruction [10]. It has been shown, for example, that there is much more bone formed in 1 week in the 
presence of bioglass ${ }^{\circledR}$ than is formed when HA or other calcium phosphate ceramic particulates are placed in the same type of defect [33]. Moreover bioglass ${ }^{\circledR}$, being a class A bioactive material (as opposed to HA, which is class B), has shown strong bond also to soft tissues [34]. The application potential of the bioglass ${ }^{\circledR}$-containing composites fabricated here, therefore, could include both hard and soft tissue regeneration and repair. The further development of PDLLA/bioglass ${ }^{\circledR}$ composite materials is interesting also due to the fact that PDLLA degrades without generation of any crystalline remnants. Heideman et al., have proved very recently, for example, the complete resorption of PDLLA implants from the extracellular space in animal studies, therefore confirming their tissue tolerance [35]. The course of degradation is more questionable for slowly degradable, crystalline PDLLA of high molecular weight. In some cases, degradation products were formed, including numerous stable and highly crystalline particles, which were responsible for a delayed inflammation and foreign body reactions at the site of implantation [36].

In the case of polymer/Bioglass ${ }^{\circledR}$ composites, the bioactive glass coating should act as a protective hydrolysis barrier affecting both the extent and rate of degradation of the polymer substrate, as found in recent investigations [20-22]. The rapid exchange of protons in water for alkali in the glass provide a $\mathrm{pH}$ buffering effect at the polymer surface, therefore acceleration of degradation will not occur due to small $\mathrm{pH}$ changes during bioactive glass dissolution. Cell culturing studies and the in vivo response of the composites is the focus of current research. In parallel developments, the in vitro behaviour of PDLLA foams incorporating $10 \mathrm{wt} \%$ of bioglass ${ }^{\circledR}$ particles as filler is being investigated. Preliminary results have not been conclusive regarding the effect of incorporation of bioglass ${ }^{\circledR}$ particles on the rate of bioresorbability of the polymer in vitro, and further research is being carried out. Whether or not the use of bioglass ${ }^{\circledR}$ as filler in PDLLA foams will contribute to enhance the mechanical properties of the scaffolds remains also to be investigated.

\section{Conclusions}

Bioactive and bioresorbable polymers were developed based on three-dimensional, macroporous poly(d,l)-lactic acid (PDLLA) foams and bioglass ${ }^{\circledR}$ particles. Two cost-effective processing techniques, namely aqueous slurrydipping and EPD were developed and optimised. The optimised slurry-dipping technique led to stable and uniform glass coatings as well as adequate infiltration of bioglass ${ }^{\circledR}$ into the porous network of the foams. A pretreatment stage of the foams in ethanol was required to decrease the hydrophobicity of the PDLLA material. The PDLLA foam/bioglass ${ }^{\circledR}$ composites were tested by means of in vitro studies in SBF to determine their potential as tissue engineering scaffolds. It was found that a thin HA coating developed after 7 days in SBF, which further grew to form a thick $(\sim 10 \mu \mathrm{m})$ and uniform HA layer on the scaffold with increasing time in SBF. The present work may open a new way for the development of porous bioresorbable scaffolds of high bioactivity for hard and soft tissue engineering. Future research should focus on tailoring novel microstructures for determined applications, including the development of composites with graded porosity and graded Bioglass ${ }^{\circledR} \quad$ coating microstructure.

\section{Acknowledgements}

Discussions with Dr. Farnaz Sharifi (Imperial College, London) are appreciated. A part of the experiments was conducted with financial support of the Nuffield Foundation, London (Grant No. NAL/00196/ G). J.A.R. acknowledges financial support of EPSRC (UK). L.L.H. acknowledges support of the UK Medical Research Council. US Biomaterials is acknowledged for the bioglass ${ }^{\circledR}$ powders. V.M. is 'Collaborateur Scientifique' by the 'Fonds National de la Recherche Scientifique', (FNRS). CERM is indebted to the 'Services Fédéraux des Affaires Scientifiques, Techniques et Culturelles', for financial support in the frame of the 'Pôles d'Attraction Interuniversitaires: PAI 4/11',

\section{References}

[1] Vacanti CA, Vacanti JP. Bone and cartilage reconstruction. In: Lanza RP, Langer R, Chick WL, editors. Principles of tissue engineering. Texas (USA): R. G. Landes Company, 1997. p. 619-31.

[2] Kellomaki M, Niiranen H, Puumanen K, Ashammakhi N, Waris T, Torm.al.a P. Bioabsorbable scaffolds for guided bone regeneration and generation. Biomaterials 2000;21:2495-505.

[3] Piskin E. Biomaterials in different forms for tissue engineering: an overview. Mater Sci Forum 1997;250:1-14.

[4] Zhang Y, Zhang M. Synthesis and characterization of macro-porous chitosan/calcium phosphate composite scaffolds for tissue engineering. J Biomed Mater Res 2001;55:304-12.

[5] Maquet V, Jerome R. Design of macroporous biodegradable polymer scaffolds for cell transplantation. Mater Sci Forum 1997;250:15-42. [6] Agrawal CM, Athanasiou KA, Heckman JD. Biodegradable PLA-PGA polymers for tissue engineering in orthopadics. Mater Sci Forum 1997;250:115-29.

[7] (a) Schugens C, Maquet V, Grandfils C, Jerome R, Teyssie P. Biodegradable and macroporous polylactide implants for cell transplantation: I. Preparation of macroporous polylactide supports by solid-liquid phase separation. Polymer 1996;37:1027-38. (b) Schugens C, Maquet V, Grandfils C, Jérôme R, Teyssié P. Biodegradable and macroporous polylactide implants for cell transplantation: 
polylactide macroporous biodegradable implants for cell transplantation. II. Preparation of polylactide foams by liquid-liquid phase separation. J Biomed Mater Res 1996;30:449-61.

[8] Agrawal CM, Ray RB. Biodegradable polymeric scaffolds for musculoskeletal tissue engineering. J Biomed Mater Res 2001;55:141-50.

[9] Schliephake H, Neukam FW, Hutmacher D, Becker J. Enhancement of bone in-growth into a porous HA-matrix using a resorbable polylactice membrane. J Oral Maxillofac Surg 1994;52:57-63.

[10] Hench LL. Bioceramics. J Am Ceram Soc 1998;81:1705-28.

[11] Verheyen CCPM, de Wijn JR, van Blitterswijk CA, de Groot K, Rozing PM. Hydroxyapatite/poly(l-lactide) composites: an animal study on push-out strengths and interface histology. J Biomed Mater Res 1993;27:433-44.

[12] Linhart W, Peters F, Lehmann W, Schwarz C, Schilling A, Amling M, Rueger JM, Epple M. Biologically and chemically optimised composites of carbonated apatite and polyglycolide as bone substitution materials. J Biomed Mater Res 2001 ;54: $162-71$.

[13] Durucan C, Brown PW. Biodegradable hydroxyapatite-polymer

composites. Adv Eng Mater 2001;3:227-31.

[14] Thomson RC, Yaszemski MJ, Powers JM, Mikos AG. Hydro-xyapatite fiber reinforced poly(a-hydroxyl ester) foams for bone regeneration. Biomaterials 1998;18:1935-43.

[15] Nazhat SN, Kellomaki M, T.ormala P, Tanner KE, Bonfield W. Dynamic mechanical characterization of biodegradable composites of hydroxyapatite and polylactides. J Biomed Mater Res (Appl Biomater) 2001;58:335-43.

[16] Ignjatovic N, Deliji!c K, Vukcevic M, Uskokovic D. The designing of properties of hydroxyapatite/poly-1-lactide composite materials by hot pressing. Z Metallkd 2001;92(2):145-9.

[17] Niiaren H, Tormala P. Bioabsorbable polymer plates coated with bioactive glass spheres. J Mater Sci Mater Med 1999;10: 707-10.

[18] Ma PX, Zhang R, Xiao G, Franceschi R. Engineering new bone tissue in vitro on highly porous poly (a-hydroxyl acids)/hydro-xyapatite composite scaffolds. J Biomed Mater Res 2001;54: 284-93.

[19] Boccaccini AR, Roether JA, Hench LL, Maquet V, Jérôme R. A composites approach to tissue engineering. Ceram Eng Sci Proc, in press.

[20] Stamboulis A, Hench LL. Bioresorbable polymers: their potential as scaffolds for bioglass ${ }^{\circledR}$ composites. Key Eng Mater 2001; 192195:729-32.

[21] Stamboulis A, Hench LL, Boccaccini AR. Mechanical properties of biodegradable polymer sutures coated with bioactive glass. J Mater Sci: Mater Med, in press.

[22] Stamboulis A, Boccaccini AR, Hench LL. Novel biodegradable polymer/bioactive glass composites for tissue engineering applications. Adv Eng Mater 2002;4:105-9.

[23] Maquet V, Blacher S, Pirard R, Pirard J-P, Jérôme R. Characterization of porous polylactide foams by image analysis and impedance spectroscopy. Langmuir 2000;16:10463-70.

[24] Blacher S, Maquet V, Pirard R, Pirard J-P, Jérôme R. Image analysis, impedance spectroscopy and mercury porosimetry characterization of freeze-drying porous materials. Colloids Surfaces A: Physicochem Eng Aspects 2001; 187-188:375-83.

[25] Maquet V, Martin D, Malgrange B, Franzen R, Schoenen J, Moonen G, Jérôme R. Peripheral nerve regeneration using bioresorbable macroporous polylactide scaffolds. J Biomed Mater Res 2000;52:639-51.

[26] Maquet V, Martin D, Scholtes F, Schoenen J, Moonen G, Jérôme R. (Poly(d,1-lactide) foams modified by poly(ethylene oxide)-blockpoly(d,1-lactide) copolymers and a-FGF: in vitro and in vivo evaluation for spinal cord regeneration. Biomaterials 2001;22:1137-46.

[27] Hench LL, Splinter RJ, Allen WC, Greenlee TK. Bonding mechanisms at the interface of ceramic prosthetic materials. J Biomed Mater Res 1971;2:117-41.

[28] Mikos AG, Lyman ML, Freed LE, Langer R. Wetting of poly (l-lactic acid) and poly(dl-lactic-co-glycolic acid) foams for tissue culture. Biomaterials 1994; 15(1):55-8.

[29] Boccaccini AR, Kaya C, Chawla KK. Use of electrophoretic deposition in the processing of fibre reinforced ceramic and glass matrix composites. A review. Composites A 2001;32:997-1006.

[30] http://sung7.kuic.kyoto-u.ac.jp/others/SBF/SBFE.html.

[31] Hutmacher DW. Scaffolds in tissue engineering bone and cartilage. Biomaterials 2001;21:2529-43.

[32] Shikinami Y, Okuno M. Bioresorbable devices made of forged composites of hydroxyapatite (HA) particles and poly-1-lactide (PLLA).

Part II: practical properties of miniscrews and mini-plates. Biomaterials 2001;22:3197-211.

[33] Hench LL, Xynos ID, Edgar AJ, Buttery LDK, Polak JM. Gene activating glasses. In: Proceedings of the Nit. Congr. Glass, vol. 1. Sheffield, UK: Society of Glass Technology, 2001. p. 226-33.

[34] Wilson J, Piggot GH, Schoen FJ, Hench LL. Toxicology and biocompatibility of bioglass. J Biomed Mater Res 1981;15:805-10.

[35] Heidman W, Jeshkeit S, Ruffieux K, Fischer JH, Wagner M, Kruger G, Wintermantel E, Gerlach K. Degradation of poly (d,1)lactide implants with or without addition of calciumpho-sphates in vivo. Biomaterials 2001;22:2371-81.

[36] Bergsma JE, de Bruijn WC, Rozema FR, Bos RRM, Boering G. Late degradation tissue response to poly(1-lactide) bone plates and screws. Biomaterials 1995;16:25-31. 